\title{
Performance of foundation-owned firms in Germany: The role of foundation purpose, stock market listing, and family involvement
}

\author{
Jörn Block $^{\mathrm{a}, \mathrm{b}, \mathrm{c}, *}$, Svenja Jarchow ${ }^{\mathrm{d}, \mathrm{e}, \mathrm{g}}$, Nadine Kammerlander ${ }^{\mathrm{f}}$, Florian Hosseini ${ }^{\mathrm{a}}$, \\ Ann-Kristin Achleitner ${ }^{\mathrm{d}, \mathrm{e}}$ \\ ${ }^{a}$ Trier University, Chair of Management, Trier, Germany \\ ${ }^{\mathrm{b}}$ Erasmus University Rotterdam, Department of Applied Economics and Erasmus Institute of Management (ERIM), Rotterdam, the Netherlands \\ ${ }^{\mathrm{c}}$ Universität Witten/Herdecke, Wittener Institut für Familienunternehmen (WIFU), Germany \\ ${ }^{\mathrm{d}}$ Technical University of Munich, Chair of Entrepreneurial Finance, Germany \\ ${ }^{\mathrm{e}}$ Center for Entrepreneurial and Financial Studies (CEFS), Germany \\ ${ }^{\mathrm{f}}$ WHU Otto Beisheim School of Management, Germany \\ ${ }^{\mathrm{g}}$ University of Hohenheim, Chair of Corporate Finance, Stuttgart, Germany
}

\section{A R T I C L E I N F O}

\section{Keywords:}

Foundation-owned firm

Performance

Foundation

Family foundation

Charitable foundation

Family involvement in the firm

\begin{abstract}
A B S T R A C T
To address succession issues, the owners of family firms increasingly transfer their equity to family and charitable foundations, thereby creating so-called foundation-owned firms. This form of succession has become increasingly common in various European countries. A small yet insightful stream of research has emerged comparing the performance of foundation-owned firms against the performance of nonfoundation-owned firms. Our study goes one step further and accounts for the heterogeneous nature of foundation-owned firms. We investigate the role of foundation purpose (family versus charitable foundation), stock market listing, and family involvement. Our results show that firms owned by a family foundation have better accounting performance than firms owned by a charitable foundation. We further find a performance-enhancing effect of family involvement in the firm's management or supervisory board. Contrary to our expectations, we did not observe significant performance differences between private and stock market-listed foundation-owned firms. Our study advances the emergent stream of the foundation-owned (family) firm literature by integrating research on foundation-owned firms with research on family firms. Furthermore, we contribute to the corporate governance literature on ownership effects and blockholder ownership.
\end{abstract}

\section{Introduction}

The owners of family firms increasingly transfer their equity to foundations, thereby creating so-called foundation-owned firms (Draheim \& Franke, 2018; Thomsen, 1999), instead of engaging in traditional intrafamily succession. Such equity transfers are motivated by manifold factors that include family-related (e.g., lack of successors and avoidance of family conflicts), philanthropic, financial (tax optimization), and corporate factors (e.g., desire for long-term planning due to a stable ownership structure) or the founder's personality (e.g., the desire to set the company purpose for eternity and to continue shaping the firm after one's death) (Achleitner \& Block, 2018; De Massis et al., 2008). This form of succession is increasingly common in the DACH region $^{1}$ and in Scandinavian countries, leading to an increasing number of foundation-owned firms in those countries (Fleisch et al., 2018). As this article was written, several well-known firms, such as Aldi, Bosch, Carlsberg, and Ikea, were partially or fully owned by foundations. Some foundation-owned firms, such as those just listed, can still be classified as family firms as the family continues to influence the company's development. Often, the founding family is the ultimate claimant of the dividends of the foundation. In addition, despite having no direct equity ownership (anymore), the family is sometimes still involved in the management and control of the firm, leaving family members many opportunities to shape the firms' activities.

A small but growing body of literature has emerged around the performance of foundation-owned firms, thereby mostly focusing on accounting performance. These studies examine the performance differences between foundation-owned firms and other types of firms (Draheim \& Franke, 2018; Dzansi, 2012; Herrmann \& Franke, 2002; Thomsen, 1996, 1999; Thomsen \& Hansmann, 2014; Thomsen \& Rose,

\footnotetext{
* Corresponding author at: Trier University, Chair of Management, Trier, Germany.

E-mail address: block@uni-trier.de (J. Block).

${ }^{1}$ The DACH region comprises the three main German-speaking countries in Europe: Germany ('D'), Austria ('A'), and Switzerland ('CH').
} 
2004). However, they provide ambiguous results. While some studies (e.g., Herrmann \& Franke, 2002) find that foundation-owned firms outperform other types of firms, most studies do not find significant performance differences (Dzansi, 2012; Thomsen, 1996; Thomsen \& Hansmann, 2014; Thomsen \& Rose, 2004). We propose that these ambiguous results stem from the heterogeneous nature of the group of foundation-owned firms, which has thus far not been accounted for in the literature on foundation-owned firms. For example, foundations as firm owners can be either family or charitable foundations, which differ substantially in their purpose and main characteristics. Charitable foundations pursue charitable purposes and are partially managed by individuals who do not possess the necessary entrepreneurial knowhow or motivation to effectively monitor the management of the firm (Achleitner et al., 2018; Maier et al., 2016; Suarez, 2010). Family foundations, in turn, primarily pursue the purpose of continued family involvement, maintaining family wealth, and preserving the founder's will (Fleschutz, 2009). In such foundations, members of the founding family are typically involved in the foundation's board. We argue that such involved family members typically show high levels of motivation and expertise for effective corporate control. Other important subgroups of foundation-owned firms are those in which the founding family is still involved in the firm's management or supervisory board and foundation-owned firms that are listed on the stock market (in contrast to private ones). Depending on the type, the family remains more or less connected and thus influences the foundation-owned firm.

This empirical study is phenomenon-driven and aims to determine how the heterogeneous group of foundation-owned firms differs in terms of accounting performance. Therefore, our particular focus is on the role of the (founding) family. Our first research goal is to determine whether there are performance differences between foundation-owned firms owned by charitable foundations and those owned by family foundations. Our second research goal is to determine whether a stock market listing has a positive or negative effect on the performance of foundation-owned firms. Third, we analyze whether the involvement of the founding family either in the management or supervisory board of the foundation-owned firm increases or decreases performance. We link our theoretical arguments to agency theory.

Using a dataset of foundation-owned firms in Germany, we find, in line with our theorizing, that foundation-owned firms owned by a family foundation have better accounting performance than firms owned by a charitable foundation. Our results further show that foundationowned firms, in which the founding family is involved in the firm (management or supervisory board), perform better than foundationowned firms without such family involvement. Finally, our results show that listed foundation-owned firms neither outperform nor underperform other foundation-owned firms.

Our study contributes to better understanding a specific type of family firm that is steadily gaining practical and theoretical relevance: those owned by a foundation. This study brings together research on foundation-owned firms with research on family firms. We contribute to two particular strands of the literature. First, our study contributes to growing research on the performance of foundation-owned firms (Achleitner et al., 2018; Draheim \& Franke, 2018; Dzansi, 2012; Herrmann \& Franke, 2002; Thomsen, 1996, 1999; Thomsen \& Rose, 2004). This literature has produced mixed results so far. We theorize and show that foundation-owned firms as a group are very heterogeneous and that substantial performance differences exist within the group of foundation-owned firms. In particular, the involvement of the founding family in the firm as well as the choice of a family (as opposed to charitable) foundation seems to make a difference for accounting performance. By hand-collecting nuanced data about foundation-owned firms and their potential dimensions of heterogeneity, we also make an important empirical contribution as we dig deeply into what is currently an underinvestigated phenomenon. Most prior works have treated foundation-owned firms as a homogeneous group and has ignored the potential differences that may exist within this group of firms.
Second, our study contributes to research on the performance effects of family involvement (Basco, 2013; Bennedsen et al., 2007; Block et al., 2011; Miller et al., 2013; Sciascia et al., 2014). Prior research argues that family managers are often characterized as having less managerial talent than nonfamily managers (Burkart et al., 2003) and explains their selection mainly through nepotism (Jaskiewicz et al., 2013; Vinton, 1998), the importance of nonfinancial goals (Chrisman et al., 2012), and possibly entrenchment and the exploitation of nonfamily shareholders (Morck et al., 2005; Volpin, 2002), which, jointly, might lead to the underperformance of family-managed firms. Our theorizing and our results indicate that these arguments do not hold true for the group of foundation-owned firms, where family involvement in the firm seems to exert a performance-enhancing effect. In addition to contributing to family firm research, our study contributes to the broader corporate governance literature on ownership effects and blockholder ownership (Morck et al., 1988; Shleifer \& Vishny, 1997). We argue and show that foundations as firm owners are not a homogenous group of blockholders but that in particular, charitable and family foundations comprise different types of blockholders, leading to heterogeneity within the group of foundation-owned firms. In addition to these contributions to the academic literature, the results of our study have implications for family firm practitioners by highlighting the effectiveness of family foundations and the potential benefits of family involvement for firm performance.

\section{Research context: foundation-owned firms}

A foundation is a legally independent institution that owns assets donated by the founder of the foundation and is set up for a certain (charitable and/or private) purpose. The assets of the foundation can be funds, real estate or (as with our study) the equity shares of a firm. Foundations are an important type of institution, as, for instance, the numbers for Germany show: According to the Federal Association of German Foundations, currently, more than 22,000 foundations exist in Germany. ${ }^{2}$ Approximately 500 new foundations are currently established per year, of which 95 percent serve charitable purposes. Most founders of foundations are individuals, but firms and the state may also act as founders and establish foundations.

Foundation-owned firms are firms that are partly or fully owned by foundations (Herrmann \& Franke, 2002; Thomsen, 2012). ${ }^{3}$ In the literature, various qualitative and quantitative criteria are used to define foundation-owned firms. One of the pioneers of this field of study, Stickrodt (1960), defines a foundation-owned firm as a firm for which a foundation owns 100 percent of firm equity. Thomsen (1996; 1999) relaxes this restrictive assumption and uses a 50 percent threshold to distinguish foundation-owned firms from other types of firms. Herrmann and Franke (2002) go even a step further and consider it sufficient if a foundation is among the firm owners, regardless of how large its specific ownership stake is. Fleschutz (2009), in turn, does not use firm equity as a defining criterion but instead refers to the influence that the foundation has on the firm. Fig. 1 below shows the typical structure of a foundation-owned firm in Germany (for a detailed overview, please refer to Moog \& Schell, 2015).

\footnotetext{
${ }^{2}$ See https://www.stiftungen.org/stiftungen/zahlen-und-daten/statistiken. html (accessed June 7, 2019).

${ }^{3}$ In the German language, the terms "Stiftungsunternehmen" and "stiftungsverbundenes Unternehmen" are used for foundation-owned firms. The corresponding foundations are referred to as "unternehmensbezogene Stiftung", "unternehmensnahe "Unternehmensstiftung", "Unternehmensträgerstiftung", "gewerbliche Stiftung", and "unternehmensverbundene Stiftung". In some international publications, the term "industrial foundations" is used (Thomsen, 2017).
} 


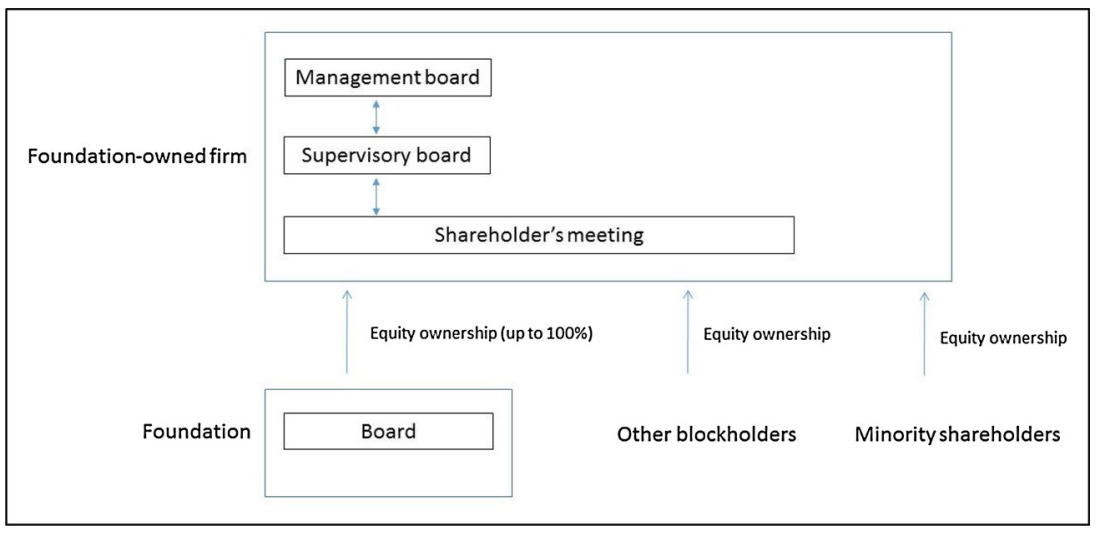

Fig. 1. Structure of a foundation-owned firm in Germany.

Source: own figure

\subsection{Establishment of a foundation and types of foundations}

Setting up a foundation differs from setting up a firm in terms of the process as well as the implications. In the following, we elaborate on the specific processes and decisions related to foundations in the German legal system. Notably, whoever transfers assets into a foundation irreversibly disposes of his or her assets and forgoes any ownership claims. Moreover, the foundation is obliged to invest the donated assets in a risk-averse and profitable manner to maintain the foundation's capital. A foundation is intended to last in perpetuity and usually cannot be dissolved. ${ }^{4}$ For the establishment of a foundation, there are only a few requirements to be fulfilled (Fricke, 2010): the founder of the foundation has to establish the "foundation business", and the responsible authority of the respective federal state ("Stiftungsaufsicht") has to approve the foundation. The foundation business ("Stiftungsgeschäft") is based on a unilateral declaration of intent (Götz \& Berndt, 2009), which contains the foundation charter ("Stiftungssatzung") and the founder's binding declaration to donate assets to the foundation to fulfill the purpose specified in the charter. The charter, which is the heart of the foundation (Heinzelmann, 2002), is generally binding and difficult to change after the founder's death. In the case of a family foundation, the charter usually codifies the role of the founding family in the foundation and describes its rights and duties regarding the foundation and the firm. Therefore, the foundation charter shares some similarities with a family constitution, which is an important part of family governance (Suess, 2014) and aims to reduce the likelihood of the occurrence of family conflicts with potentially detrimental consequences (Arteaga \& Menéndez-Requejo, 2017; Frank et al., 2011). The charter contains the name, registered office, purpose, assets, and organization of the foundation.

The purpose of the foundation ("Stiftungszweck") is often described as the most important aspect of the charter, since it concerns the foundation's identity and since its assets as well as its organization are geared towards the purpose (Heinzelmann, 2002; Kronke, 1988). A foundation may have several purposes, which can be generally classified as either a charitable or private nature (Fritsche \& Kilian, 2008). There are basically no limits regarding the purpose of a to-be-installed foundation; the purpose must be attainable, and it must not endanger the common good. In addition, a continuous, sustainable fulfillment of the foundation's purpose must be guaranteed, which, in contrast to association or company law, means that it is almost impossible to change the purpose of the foundation at a later point in time (Heinzelmann, 2002). In addition to the purpose, the foundation's

\footnotetext{
${ }^{4}$ The only exception is the consumption foundation ("Verbrauchsstiftung"), which is created for a limited time period and should consume all its assets to fulfill the foundation's purpose.
}

assets ("Stiftungsvermögen") are an important feature of the foundation charter. Under German law, there are no requirements or restrictions on the assets that a foundation could possess (Kronke, 1988). In many cases, the assets comprise cash, land, securities, and equity. The assets need to be preserved, and generally, the profits generated from the foundation's assets should be distributed to the foundation's projects (von Camphausen \& Richter, 2014). In addition, the boards of the foundation have to manage the assets in such a way that the purpose of the foundation is maintained.

Another important aspect of the charter is the organization of the foundation, which can be freely determined by the founder. In the German context, the only legal requirement is the existence of a management board, regardless of its form and size. As there is no compulsory external accounting of foundations (Kennedy et al., 1998) and due to the fact that the supervisory boards of foundations are voluntary, foundations are subject to state supervision. This stipulation serves to protect the foundation from misconduct on the part of the foundation board and to ensure that the founder's will regarding the foundation business is fulfilled (Heinzelmann, 2002).

Foundations are heterogeneous by nature and differ with regard to their functioning (grant-making versus operational), size, age, and legal capacity. For the purpose of our study, we distinguish between charitable and family foundations, which have different purposes. Charitable foundations use the returns from their assets to finance charitable projects, whereas the beneficiaries of family foundations are the families and their individual members. As the name suggests, a charitable foundation must serve the common good; its purpose is to achieve cultural, social, ecological, and scientific goals. ${ }^{5}$

A family foundation, however, serves private purposes and supports the founder's family (Brandmüller \& Lindner, 2004). As such, returns from assets can be freely used by the family members. In other words, while family members, in the case of family foundations, no longer possess ownership rights, they still financially benefit from their roles as beneficiaries. Family and charitable foundations differ not only in their purpose but also regarding their treatment by the German tax system. ${ }^{6}$ Since serving the common good has certain privileges under German tax law, charitable foundations are treated differently than family foundations, e.g., the latter have to pay an equivalent of an inheritance tax as well as taxes when there has been an endowment. However, if the assets are transferred to a charitable foundation either before or

\footnotetext{
${ }^{5}$ Note that charitable foundations do not need to distribute $100 \%$ of their dividends to charitable projects and are allowed to make small financial payments to family members.

${ }^{6}$ See also Henrekson et al. (2019), who discuss the role of tax incentives for the creation of private foundations as controlling owners of Swedish listed firms.
} 
immediately after death, as defined in the last will, no inheritance tax has to be paid.

\subsection{Foundations as a succession option and their competitive (dis-) advantages}

Why do founders or business-owning families choose this particular form of succession instead of other forms? The reasons are manifold. In addition to charitable or philanthropic ambitions, such as promoting science, regional support, ecological goals, or caring for employees (Zeiter, 2004), family-related issues may play an important role. The transfer of equity into a foundation can be an attractive succession option when no adequate heir is available or in the case of sibling conflicts (De Massis et al., 2008; Friedman, 1991; Zellweger \& Kammerlander, 2015), as it delegates ownership and leadership tasks to outsiders while at the same time avoiding selling the firm to external parties and leaving opportunities for family members to remain connected to the firm. The potential for family conflicts is reduced as disputes over inheritance and succession in these firms can be avoided by a clear regulation in the foundation charter. This regulation applies not only to the next generation but also to future generations. Moreover, setting up a foundation might allow the founder to provide for the future care for the family (Block \& Hosseini, 2017). The founder's family can be continuously provided the resources that they need. In a family foundation, the family as the beneficiary will continue to profit from the firm's dividends. The family charter can precisely regulate which family members or family tribes benefit from the foundation and in what form. These benefits can be regular payments or one-off payments for a specific purpose (e.g., education). Such regulations can also prevent the family members from living a spendthrift lifestyle. Furthermore, by setting up the charter, the founder shapes the foundation for eternity, far beyond his or her death. For many founders, this continued influence beyond their death is a key motivation for establishing a (family) foundation (Sharma et al., 2001).

In addition to these family considerations, founders might establish foundations due to firm considerations, e.g., because they want to keep the company independent and avoid (hostile) takeovers (Scholes et al., 2010). Finally, tax considerations can also be a decisive factor, as charitable foundations are exempt from inheritance taxes. In addition, a charitable foundation is usually favorably perceived by the public, thus enhancing the reputation that may spill over to the family.

From a firm perspective, the most important advantage is that the firm will no longer be led by short-term driven owners, as there are typically no majority shareholders who insist on paying out the highest possible dividend. Therefore, the management of a foundation-owned firm is relieved of the pressure to achieve short-term optimization to the detriment of long-term prosperity. This freedom enables foundationowned firms to better plan for the long term and gain a competitive advantage (Draheim, 2016). A further advantage of specifically charitable foundations is that they typically enjoy excellent reputations in society that might spill over to the firm. One advantage of family foundations as owners is that family members are often still close enough to the firm to potentially be available as advisors or for representative tasks, thereby providing important human capital to the firm.

Despite these positive aspects, from the founder perspective, setting up a foundation-owned firm might also have disadvantages, such as conflicts within the family. In particular, family members might be unsatisfied that they are not being considered successors. For example, the founder of Playmobil, Horst Brandstetter, transferred the shares of his firm into a foundation because he did not trust his son to be able to run the firm and out of fear that he would make too many changes to the firm. Not surprisingly, his son was disappointed with this decision. ${ }^{7}$
Such dissatisfaction might even be increased in the case of a charitable foundation, which limits payments to family members. Long-lasting legal proceedings might follow. From the firm perspective, the main disadvantage is the potential inability of the firm to react in a flexible manner to changing technological, political, or economic conditions, thus becoming slow and uncompetitive (Achleitner et al., 2018). These problems can be caused by a rather inflexible and restrictive foundation charter. Moreover, foundation-owned firms might face problems raising (equity) capital and grow through acquisitions, as the foundation may not be allowed to sell shares or become a minority owner of the firm (Achleitner et al., 2018). Another potential disadvantage is that boards, especially those of charitable foundations, are often staffed with individuals from a nonprofit background lacking industry expertise or entrepreneurial and managerial know-how to effectively control management, which can result in managers acting opportunistically (Zellweger \& Kammerlander, 2015), causing damage to the firm. As a result, recent research by Draheim and Franke (2018) finds that foundation-owned firms can sometimes be overstaffed and very labor intensive, which they explain by a strong stakeholder orientation, particularly toward employees and managers. Table 1 below summarizes the advantages and disadvantages of foundation-owned firms compared to other firms.

\section{Literature review and hypotheses development}

\subsection{Research on blockholder ownership and its performance effects}

Corporate governance research has long been concerned with the effects of ownership structures and blockholder ownership on firm strategy and firm performance (Graves \& Waddock, 1990; Holderness, 2003). Within this large stream of research, blockholders have received particular attention. Blockholders are defined as shareholders owning a substantial share of a company's stock. ${ }^{8}$ Foundations as firm owners can be considered blockholders as they typically own a company either fully or with a sizeable share. Two broad perspectives exist in the corporate governance literature on the performance effects of blockholder ownership. Both perspectives are grounded in agency theory. The convergence-of-interest hypothesis (De Miguel et al., 2004; Morck et al., 1988) suggests that blockholder ownership has a positive effect on firm performance and shareholder value because blockholders as owners have both a strong incentive as well as the expertise and power to effectively monitor a firm's management (Jensen \& Meckling, 1976; Zeckhauser and Pund, 1990). The entrenchment hypothesis (Morck et al., 1988), in contrast, suggests a negative effect. According to this perspective, concentrated ownership may lead to the entrenchment of blockholders and managers, resulting in the expropriation of minority shareholders (Morck et al., 1988; Shleifer \& Vishny, 1997). Early studies on blockholder ownership investigate the performance effects of concentrated ownership (Agrawal \& Mandelker, 1990; Barclay \& Holderness, 1990; Bethel et al., 1998; Holderness, 2003; Holderness \& Sheehan, 1988; Lewellen et al., 1985). Later studies distinguish between different types of blockholders. Achleitner et al. (2011) and Renneboog et al. (2007), for example, investigate the shareholder value effects of private equity ownership in Germany and the UK and find positive effects. Similar results are obtained for hedge funds as firm owners (Bessler et al., 2015; Brav et al., 2008). With regard to banks as blockholders, the findings are mixed. Boehmer (2000) reports that banks have a positive effect on shareholder value only if there exists a second blockholder in the firm. The literature regarding families as

\section{(footnote continued)}

vermeintliche-fuehrungsproblem/13678996-3.html (accessed June 6, 2019).

${ }^{8}$ The exact definition of what can be considered 'substantial', however, depends on country-specific factors such as the country's system of corporate governance. 
Table 1

Advantages and disadvantages of foundation-owned firms.

\begin{tabular}{|c|c|}
\hline Advantages & Disadvantages \\
\hline $\begin{array}{l}\text { Perspective of the founder or founding family } \\
\text { - Structure and scope of the firm is kept according to the wishes of the founder. } \\
\text { - Family conflicts over succession can be avoided or reduced. } \\
\text { - Future family generations can receive a stable income through dividends } \\
\text { (through the family foundation). } \\
\text { - No or reduced inheritance tax (applies only to charitable foundations). } \\
\text { - Solution to ownership succession if no heir is available. }\end{array}$ & $\begin{array}{l}\text { Perspective of the founder or founding family: } \\
\text { - Family members may feel upset as the founder seems not to have trust in their } \\
\text { competence as owners and/or managers. } \\
\text { - Formulating the foundation charter may be difficult and challenging. }\end{array}$ \\
\hline $\begin{array}{l}\text { Perspective of the firm } \\
\text { - Foundations are patient and long-term oriented shareholder. } \\
\text { - Foundations do not seek to maximize dividend payments allowing the firm to } \\
\text { invest into R\&D and other long-term projects. } \\
\text { - Positive reputation spillovers of being a foundation-owned firm can create a } \\
\text { positive image for employees and customers (applies mostly to charitable } \\
\text { foundations). }\end{array}$ & $\begin{array}{l}\text { Perspective of the firm } \\
\text { - Reduced flexibility of the firm to raise additional equity from capital markets. } \\
\text { divest business units. } \\
\text { - Foundations may not have the competence and expertise to effectively control the } \\
\text { management of the foundation-owned firm which can lead to opportunistic behavior } \\
\text { (applies particularly to charitable foundations). } \\
\text { - The concept, functioning, and structure is mostly unknown outside the DACH region } \\
\text { which can lead to misunderstandings and communication problems. } \\
\text { - Due to strong employee orientation foundation-owned firms are sometimes overstaffed. }\end{array}$ \\
\hline
\end{tabular}

blockholders is already very advanced, and several meta-analyses exist (O’Boyle et al., 2012; Hansen \& Block, 2020; Hansen et al., 2020; Wagner et al., 2015). Family ownership seems to have a statistically significant but economically small positive effect on firm performance. However, considerable heterogeneity exists with regard to performance, which can be explained by the heterogeneous nature of family firms and family ownership. Compared to the large body of literature on family firm performance, only a few studies to date have examined the performance effects of foundations as firm owners. We briefly review this literature in the next section before we derive our hypotheses regarding the performance differences within the group of foundationowned firms.

\subsection{Research on the performance of foundation-owned firms}

Prior research has started to investigate the performance of foundation-owned firms. Some studies report a positive effect of foundation ownership on firm success (e.g., Draheim, 2016; Herrmann \& Franke, 2002) due to those firms' long-term orientation. Similar to families as owners, foundations have a strong long-term interest in the firm. Foundations cannot easily sell their equity stakes in the firm because their foundation charter typically restricts them from doing s. Hence, foundations are patient firm owners or investors who care about the long-term development of the firm that they own. Having such a longterm oriented, patient owner can be a competitive advantage for foundation-owned firms because it allows them to invest continuously in innovation and other long-term projects (Harford et al., 2018). Other studies, however, find negative (e.g., Achleitner et al., 2018) or nonsignificant effects (Dzansi, 2012; Thomsen, 1996; Thomsen \& Rose, 2004) of foundation ownership on firm performance. These studies typically take an agency perspective and argue that foundation-owned firms and foundations as owners suffer from problems concerning the monitoring of management. The lack of strong, business-oriented principals might lead to a lack of corporate control and can result in forgoing entrepreneurial opportunities. Draheim and Franke (2018), for example, describe foundation-owned firms as firms without powerful residual claimants, leading to weak corporate governance. Moreover, foundation-owned firms pursue a strong stakeholder orientation at the expense of financial performance, which might result from a lack of corporate control by strong, knowledgeable shareholders. Stakeholders, such as the firm's employees or management, fill the void and pursue their own interests at the expense of the firm's interests and profitability. In line with this argumentation, prior research shows that foundation-owned firms are sometimes overstaffed and pay aboveaverage wages (Børsting and Thomsen, 2017; Draheim \& Franke, 2018).
To summarize, there is mixed evidence about the performance of foundation-owned firms compared to other firms. We argue that prior research has so far failed to capture the full heterogeneity that exists within the group of foundation-owned firms. Indeed, most prior research has treated foundation-owned firms as a homogenous group and has compared the performance of foundation-owned firms against the performance of other types of firms. To date, little is known about the performance differences within the group of foundation-owned firms. Our study aims to close this important gap.

\subsection{Performance differences within the group of foundation-owned firms}

In this section, we develop three hypotheses about performance differences within the group of foundation-owned firms. Similar to most prior research on blockholder ownership, we use agency theory as the theoretical framework. In particular, we distinguish between the interest alignment (De Miguel et al., 2004; Morck et al., 1988) and entrenchment effects (Morck et al., 1988) of blockholder ownership. Hypothesis 1 concerns the differences in the performance effects of charitable versus family foundations as firm owners. Hypothesis 2 refers to the differences between listed and non-listed (i.e., privately held) foundation-owned firms. Finally, Hypothesis 3 addresses the differences between foundation-owned firms in which the founding family is involved in the firm and foundation-owned firms in which this is not the case.

\subsubsection{Charitable foundations versus family foundations and the performance of foundation-owned firms}

In alignment with our discussion about the differences between charitable and family foundations in Section 2.1 above, we argue that compared to family foundations, charitable foundations have more difficulty with and are less efficient in monitoring the management of the foundation-owned firm. Hence, from an agency theory perspective, the interest alignment between the shareholders of the firm (i.e., the foundation) and managers of the firm should be lower for charitable foundations than family foundations. This lack of interest alignment in firms owned by charitable foundations might negatively affect accounting performance.

A charitable foundation uses the dividends it receives from the firm for charitable purposes, as defined in the foundation charter. Taking the agency perspective, this implies that the final beneficiaries of the dividends have no control or voting rights to influence the decisions of the foundation or the foundation-owned firm. While this is in strong contrast to other firm owners who are typically individuals with residual claims and control rights (Thomsen, 1999) in general, we argue that charitable foundations face greater difficulties than family 
foundations in monitoring the firm's management. The reason is that charitable foundations typically employ and are managed by individuals with a professional background in the social or charitable sector (Maier et al., 2016; Suarez, 2010), who often lack the expertise needed to effectively monitor the firm's management. This allows management to act opportunistically at the expense of the firms' development and profitability. Family foundations, in contrast, are frequently managed and governed by descendants of the firm's founder. We argue that the family members in family foundations who monitor the firm's management possess the capability and motivation to do so because of family tradition, existing industry or management expertise, and, most importantly, the fact that they receive dividends. A model by Hillman and Dalziel (2003) shows that boards with greater monitoring incentives have a positive effect on firm performance. These arguments lead us to our first hypothesis:

Hypothesis 1. Foundation-owned firms owned by a family foundation have better accounting performance than foundation-owned firms owned by a charitable foundation.

\subsubsection{Stock market listing and the performance of foundation-owned firms}

Like any other type of firm, foundation-owned firms can be listed on the stock market. From the agency theory perspective, a stock market listing is a double-edged sword. On the one hand, it can lead to better monitoring or disciplining of management (Holmström \& Tirole, 1993; Pagano et al., 1998; Pagano \& Röell, 1998). Firms that are listed on stock markets are under greater public scrutiny and are constantly monitored by financial analysts. This puts pressure on management to make decisions leading to strong (accounting and market-related) firm performance. In this way, the stock market might compensate for the lack of effective control by an incompetent and ineffective foundation (Achleitner et al., 2018). All of these stock market-related benefits can help the firm grow and develop and lead to better firm performance.

On the other hand, the strong stock market-induced performance expectations regarding the firm's management can also have disadvantages such as stock-market myopia (Abarbanell \& Bernard, 2000; Laverty, 1996; Marginson \& McAulay, 2008). From the agency theory perspective, stock-market myopia can occur because it is easier to measure short-term performance than long-term performance. Hence, to meet the expectations of the stock market, managers have a strong incentive to focus on short-term rather than long-term performance and to engage in short-termism, which can manifest itself in decreased investments in R\&D and innovation (Bushee, 1998; Chen et al., 2015), endangering the firm's competitive position and future performance (Brauer, 2013). The reason for this short-termism is that the funds supplied via the stock market often come from impatient investors, such as investment or hedge funds. These investors can move their funds more quickly than other investors and therefore do not understand - or care about - the firm's long-term prospects (Bushee, 1998). Managers know about this investor behavior and are forced to think in the short term to avoid the risk of a firm takeover (Stein, 1988) or the loss of their jobs (Palley, 1997). Additionally, quarterly reporting is a characteristic of stock markets that can induce short-term managerial behavior (Stein, 1989).

Despite such potential drawbacks, however, we argue that, for the case of foundation-owned firms, the benefits of a stock market listing outweigh the disadvantages. Foundations are powerful blockholders and, almost by definition, patient and long-term investors. Recent research by Harford et al. (2018) shows that long-term investors improve corporate governance and reduce managerial misbehavior such as earnings management and financial fraud. In addition, long-term investors have positive effects on innovation quality and quantity as well as firm profitability. In short, our argument is that the danger of stock market or managerial myopia is lower in foundation-owned firms than in other types of stock market listed firms, leading to an emphasis on the benefits that accompany stock market listings. These arguments bring us to our second hypothesis:

Hypothesis 2. Listed foundation-owned firms have better accounting performance than non-listed foundation-owned firms.

\subsubsection{Family involvement in the firm and the performance of foundation- owned firms}

Prior research shows that the performance effects of family involvement vary strongly and depend on contextual factors (Miller et al., 2013; Wagner et al., 2015). Family management, for example, can have both positive and negative impacts on firm performance. These outcomes can be explained from the agency theory perspective. On the positive side, members of the founding family grew up with the firm and often have substantial knowledge of the firm and its processes (Miller \& Le Breton-Miller, 2006). Moreover, their family role may facilitate intergenerational knowledge transfer and knowledge management (Jaskiewicz et al., 2013). Finally, the family members often identify strongly with the firm, have high intrinsic motivation, and can act as effective agents motivating employees and other stakeholders of the firm (Davis et al., 2010; Miller \& Le Breton-Miller, 2006). There is a strong incentive alignment between the interests of the firm and the family members. This alignment reduces agency costs and can have performance advantages. On the negative side, there can be problems of entrenchment and nepotism, where a family member may act opportunistically and use the firm's resources for his or her personal activities (Bandiera et al., 2017) or help the business-owning family exploit nonfamily shareholders (Morck et al., 2005; Volpin, 2002). Second, as the pool of suitable family members is limited, management or control positions might be filled with family members who do not have sufficient talent, expertise, and management know-how (Bennedsen et al., 2007). Employing incompetent and untalented family managers can further increase the agency costs related to entrenchment.

We argue that foundations as owners reduce the likelihood of incompetent or opportunistic family members being involved in the firm. In fact, a common motive for founders to transfer their equity to a foundation is to protect the firm from mismanagement by his or her own family (De Massis et al., 2008; Friedman, 1991). Therefore, foundation-owned firms most likely employ only members of the founding family who have sufficient entrepreneurial and managerial know-how to successfully manage and/or control the firm. Next, with the transfer of ownership to the foundation, the founding family reduces its influence on the firm, making it harder to nominate (incompetent) family members for the firm's management and/or supervisory boards. As described above, the foundation is a self-governing institution that has to follow the foundation charter rather than the family's interests. Due to the mitigation of the negative factors, we posit that for foundation-owned firms, the positive aspects of family involvement outweigh the negative aspects. In other words, the reduction in agency costs related to strong interest alignment outweighs the additional agency costs that can occur due to entrenchment. This leads us to our third hypothesis:

Hypothesis 3. Foundation-owned firms in which the founding family is involved in the firm have better accounting performance than other foundation-owned firms.

\section{Data and method}

\subsection{Sample and data sources}

The focus of our study is on German foundation-owned firms. Aside from Germany, foundation-owned firms are also common in many European countries, such as Switzerland, Austria, Belgium, the Netherlands, Luxembourg, and Scandinavian countries. In the U.S., foundation-owned firms do not play a substantial role to date, as foundations or trusts are not allowed to own more than 20 percent of a 
Table 2

Description of variables.

\begin{tabular}{|c|c|}
\hline Variable & Description \\
\hline \multicolumn{2}{|l|}{ Dependent variables } \\
\hline $\operatorname{RoS}$ & Average return on sales $(2006-2016)^{*}$ \\
\hline RoI & Average return on investment $(2006-2016)^{*}$ \\
\hline RoA & Average return on assets $(2006-2016) *$ \\
\hline \multicolumn{2}{|l|}{ Independent variables } \\
\hline Charitable foundation & Dummy for whether the foundation is a charitable or a family foundation $* * *$ \\
\hline Listed firm & Dummy for whether the firm is listed on the stock exchange or not $* * *$ \\
\hline Family involvement & Dummy for whether the (founding) family is involved in the management or supervisory board * \\
\hline \multicolumn{2}{|l|}{ Control variables } \\
\hline Percentage of foundation ownership & Percentage of firm ownership held by the foundation $* *$ \\
\hline Firm size & Average number of employees $(\log )(2006-2016) *$ \\
\hline Sales growth & Average sales growth between 2006 and $2016 *$ \\
\hline Debt-equity-ratio & Total liabilities divided by total equity * \\
\hline Firm age & Age of the firm in years $* *$ \\
\hline \multicolumn{2}{|l|}{ Industry categories } \\
\hline Professional, scientific and technical activities & Dummy for firms active in professional, scientific and technical activities * \\
\hline Manufacturing & Dummy for firms active in manufacturing * \\
\hline Retail & Dummy for firms active in wholesale and retail trade, repair of motor vehicles and motorcycles * \\
\hline Other industries & Dummy for firms active in other industries * \\
\hline
\end{tabular}

* Amadeus database.

** Hoppenstedt database.

$* * *$ self-reported.

firm's equity (Fleishman, 2003).

During data collection, we identified 372 foundation-owned firms in Germany. We started with a list of German foundation-owned firms generated from Fleschutz (2009) and Besecke (2015) and extended this list with the help of data from the Federal Financial Supervisory Authority (BAFIN) and other databases, such as Hoppenstedt and Amadeus. As many of the identified 372 foundation-owned firms are excluded from the disclosure obligation (less than 12 million $€$ turnover or less than 250 employees), they do not have to publish their income statements. Thus, accounting data were available for 136 foundationowned firms for the period of 2006-2016.

We used the Amadeus database to collect the accounting data of these firms. Subsequently, additional data were collected manually from the German Federal Gazette (Bundesanzeiger). In addition to the accounting data, we collected information on the firms' ownership structures using the Hoppenstedt database. We used the NACE Rev.2 codes for industrial classification. Table 2 provides an overview of our variables, and Table 3 provides an overview of our sample.

Among the 136 foundation-owned firms in our sample, 30 firms are (partly) owned by a family foundation, 106 firms are (partly) owned by a charitable foundation, 23 firms are listed on a stock exchange, and 28 firms have family involvement in management. The mean ownership share of the foundation in the foundation-owned firm is $64.3 \%$. By industry classification, manufacturing accounts for $36 \%$ and retail accounts for $31 \%$ of the firms in our sample. The firms in our sample are relatively large and old. The mean age is 67 years, and the mean number of employees is 13,496 .

\subsection{Empirical analyses}

To test our hypotheses, we use a linear regression for four different performance measures.

\subsubsection{Dependent variables}

The dependent variables are Return on Sales (ROS), Return on Investments (ROI), and Return on Assets (ROA). These three variables are chosen because they are the most common profitability indicators used to assess firm accounting performance. We based our selection of variables on previous studies that have examined the accounting performance of foundation-owned firms (Draheim \& Franke, 2018; Herrmann \& Franke, 2002; Thomsen, 1996) and family firms (Andres, 2008). Using the Amadeus database, we collected data for the period 2006-2016 for all three variables and used their average for our calculations.

Table 3

Descriptive statistics and correlations.

\begin{tabular}{|c|c|c|c|c|c|c|c|c|c|c|c|c|c|c|c|c|}
\hline & Mean & SD & 1 & 2 & 3 & 4 & 5 & 6 & 7 & 8 & 9 & 10 & 11 & 12 & 13 & VIF \\
\hline 1. ROS & 5.07 & 0.67 & & & & & & & & & & & & & & \\
\hline 2. ROI & 4.48 & 0.50 & 0.68 & & & & & & & & & & & & & \\
\hline 3. ROA & 6.36 & 0.53 & 0.56 & 0.94 & & & & & & & & & & & & \\
\hline 4. Charitable foundation & 0.71 & & -0.21 & -0.14 & -0.14 & & & & & & & & & & & 1.04 \\
\hline 5. Listed firm & 0.19 & & -0.01 & 0.01 & 0.04 & 0.10 & & & & & & & & & & 1.26 \\
\hline 6. Family involvement & 0.26 & & 0.13 & 0.27 & 0.26 & 0.02 & 0.02 & & & & & & & & & 1.17 \\
\hline 7. Manufacturing & 0.36 & & -0.11 & -0.09 & -0.08 & -0.01 & 0.12 & -0.07 & & & & & & & & 1.34 \\
\hline 8. Retail & 0.31 & & -0.12 & -0.05 & -0.06 & 0.01 & -0.08 & 0.01 & -0.19 & & & & & & & 1.17 \\
\hline 9. Other industries & 0.10 & & 0.07 & -0.06 & -0.08 & -0.00 & -0.03 & 0.01 & -0.33 & -0.16 & & & & & & 1.39 \\
\hline 10. Percentage of foundation ownership & 64.27 & 3.29 & 0.12 & 0.07 & 0.05 & 0.00 & -0.35 & 0.10 & 0.01 & -0.13 & 0.08 & & & & & 1.25 \\
\hline 11. Firm size & 3.19 & 0.08 & -0.00 & 0.17 & 0.21 & 0.12 & 0.22 & 0.31 & 0.08 & -0.05 & -0.24 & -0.05 & & & & 1.26 \\
\hline 12. Sales growth & 31.73 & 4.77 & 0.35 & 0.31 & 0.33 & 0.08 & -0.08 & 0.01 & -0.10 & 0.02 & 0.01 & 0.14 & 0.12 & & & 1.14 \\
\hline 13. Debt-equity-ratio & 125.52 & 9.85 & -0.28 & -0.29 & -0.35 & 0.07 & -0.05 & 0.01 & -0.06 & 0.04 & -0.08 & -0.10 & 0.03 & -0.09 & & 1.05 \\
\hline 14. Firm age & 67.73 & 3.81 & -0.03 & -0.05 & -0.00 & -0.00 & -0.20 & -0.11 & -0.06 & 0.01 & 0.09 & -0.11 & -0.04 & 0.19 & 0.01 & 1.10 \\
\hline
\end{tabular}

Coefficients with an absolute value larger than 0.05 are significant at 5 percent level and are highlighted in bold. 


\subsubsection{Independent and control variables}

The main goal of this study is to determine how the heterogeneous group of foundation-owned firms differs in terms of performance. For this purpose, three dummy variables are created to capture the independent variables. The variable charitable foundation indicates whether the firm has a charitable or a family foundation as a shareholder. ${ }^{9}$ The influence of a stock exchange listing on performance is tested by the variable listed foundation-owned firm. To create this variable, we checked the Hoppenstedt database to determine whether each firm is listed on the stock exchange. The variable family involvement indicates whether the founding family is involved in the management board or supervisory board of the firm. This information was obtained through the Amadeus database. We also checked whether there were changes in the involvement of the family in the firm between 2006 and 2016, but we did not observe any such changes.

In addition, we collected information on control variables. The variables firm size (average number of employees (log) (2006-2016)) and firm age (in years) are used to control for effects related to the size or the life cycle of the firm. We use industry dummies to control for different industries based on NACE Rev.2 codes for industrial classification. Three industries are frequently represented in our sample and are covered by the variables professional/scientific/technical activities, manufacturing, and retail (wholesale and retail trade, repair of motor vehicles and motorcycles). Other industries is a variable used to indicate firms active in industries that do not occur more than four times in our sample. To control for the ownership structure and the influence of the foundation on the firm, we included the variable percentage of foundation ownership (number of shares held by the foundation as a percentage of total equity). The variable debt-equity-ratio is used to control for the effects relating to the firm's capital structure. Finally, the variable sales growth (average sales growth between 2006 and 2016) is used to control for firms that follow an aggressive growth strategy. The correlations and descriptive statistics are provided in Table 3.

The correlation table shows only a few significant correlations between the independent variables. In addition to the correlations, we also calculated variance inflation factors (VIFs). The results show that multicollinearity is unlikely to be a concern for our study. The average VIF is 1.20 , and the maximum VIF is 1.39 (variable other industries).

\section{Results}

The results of the linear regressions are reported in Table 4 and show that firms owned by a family foundation perform better than firms owned by a charitable foundation. These results apply to all three performance measures: ROS, ROI, and ROA. Thus, we find strong support for Hypothesis 1. The accounting performance of foundationowned firms listed on the stock exchange is not significantly different from the performance of nonlisted firms. Hence, we find no support for Hypothesis 2. We observe a positive effect of family involvement on the accounting performance of foundation-owned firms. The respective coefficient is positive and statistically significant with regard to ROI and ROA. No effect is found with regard to ROS. Hence, we find partial support for Hypothesis 3. The magnitude of the detected effects is economically important. The average ROA of firms owned by family foundations is 3.03 percentage points higher than that of firms owned by a charitable foundation; the involvement of the family in the foundation-owned firm increases the firm's ROA by 2.49 percentage points.

With regard to the control variables, the results show a statistically significant negative effect of the debt-equity ratio; sales growth has a significant, positive influence. The variables firm age, firm size and percentage of foundation ownership do not have statistically significant

\footnotetext{
${ }^{9}$ The sample does not contain any firm that is owned by both a charitable and a family foundation (also known as "Doppelstiftung"). See Moog and Schell (2015) for more details.
}

effects on the performance of foundation-owned firms.

\section{Discussion}

\subsection{Summary of the main results}

We use a hand-collected, rich dataset of foundation-owned firms to shed light on the heterogeneity of these firms. As such, our phenomenon-driven paper is among the first to analyze how foundation-owned firms differ from each other and sheds light on the heterogeneity of foundation-owned firms. In line with our theoretical arguments, the analyses show that firms owned by family foundations outperform firms owned by charitable foundations. However, contrary to our expectations, a stock market listing does not result in increased performance. Interestingly, and in contrast to some prior family firm research (Bennedsen et al., 2007; Morck et al., 2005), the direct involvement of family members in the firm increases the performance of foundationowned firms. Our main findings are linked to different literature streams, which we describe in detail below.

\subsection{Implications for research about family businesses and foundation- owned firms}

As many foundations are family foundations or charitable foundations in which family members are engaged, our study adds to the family business literature. Furthermore, most foundations originate due to the succession decision regarding a family-owned firm. Therefore, research on family businesses and foundation-owned firms are strongly related.

Among the group of foundation-owned firms, involvement of the founding family in the firm seems to have a positive effect on firm performance. This result is in contrast to that of many studies in the family firm literature reporting negative or nonsignificant performance effects of family involvement (Basco, 2013; Bennedsen et al., 2007; Sciascia et al., 2014; Wagner et al., 2015). With this result, we contribute to a more nuanced view about the performance effects of family involvement (Miller et al., 2013). It seems that powerful foundations as firm owners can act as a barrier to incompetent family members being involved in the firm, and only the positive aspects of family involvement prevail for foundation-owned firms. In addition to contributing to the family firm literature, our study contributes to research about foundations as firm owners (Draheim, 2016; Fleisch et al., 2018, Fleschutz, 2009), particularly the literature on the performance implications of foundation ownership (Dzansi, 2012; Herrmann \& Franke, 2002; Thomsen, 1996; Thomsen \& Rose, 2004). As was already noted in our introduction, thus far, little is known about performance differences within the group of foundation-owned firms. Our study shows that family-related factors, such as having a family foundation or family involvement in the firm, are important drivers of performance differences. Through our findings, our study connects the emerging research stream about the behavior and performance of foundation-owned firms with the family firm literature.

The results of our analysis show that firms owned by family foundations outperform firms owned by charitable foundations. These results are in line with our theoretical arguments that charitable foundations may lack the managerial know-how needed to effectively monitor and control the firm's management (Achleitner et al., 2018; Maier et al., 2016; Suarez, 2010). The charitable foundation part of our study relates to research about philanthropy in family firms (e.g., Campopiano et al., 2014; Feliu \& Botero, 2016). Foundations are an important vehicle for business families and their family firms to practice philanthropy. However, typically, these foundations do not own equity or act as firm owners, which makes the phenomenon and study of foundation-owned firms very insightful and special. By transferring equity into a charitable foundation, the business owner clearly shows "a manifestation of a voluntary commitment to the well-being of others" 
Table 4

Results of linear regressions on the performance of foundation-owned firms.

\begin{tabular}{|c|c|c|c|c|c|c|}
\hline & \multicolumn{2}{|l|}{ ROS } & \multicolumn{2}{|l|}{ ROI } & \multicolumn{2}{|l|}{ ROA } \\
\hline & Coeff. (SE) & Coeff. (SE) & Coeff. (SE) & Coeff. (SE) & Coeff. (SE) & Coeff. (SE) \\
\hline H1 Charitable foundation & & $-4.818^{* * *}(1.275)$ & & $-3.168^{* * *}(0.857)$ & & $-3.031 * *(1.221)$ \\
\hline H2 Listed firm & & $1.842(1.502)$ & & $0.857(0.824)$ & & $0.630(1.461)$ \\
\hline H3 Family involvement & & $-0.037(1.349)$ & & $1.267 *(0.740)$ & & $2.487^{*}(1.304)$ \\
\hline Percentage of foundation ownership & $0.525(1.254)$ & $0.868(1.291)$ & $0.076(0.711)$ & $0.105(0.709)$ & $0.359(1.177)$ & $0.313(1.236)$ \\
\hline Firm size & $-0.741(0.586)$ & $-0.652(0.594)$ & $0.435(0.333)$ & $0.339(0.327)$ & $1.028 *(0.547)$ & $0.819(0.571)$ \\
\hline Sales growth & $0.042^{* * *}(0.010)$ & $0.047^{* * *}(0.009)$ & $0.023^{* * *}(0.005)$ & $0.025^{* * *}(0.005)$ & $0.027^{* * *}(0.009)$ & $0.028^{* * *}(0.009)$ \\
\hline Debt-equity-ratio & $-0.012^{* * *}(0.004)$ & $-0.011^{* * *}(0.004)$ & $-0.009^{* * *}(0.002)$ & $-0.009 * * *(0.002)$ & $-0.014^{* * *}(0.004)$ & $-0.013^{* * *}(0.004)$ \\
\hline Firm age & $0.0004(0.012)$ & $0.007(0.012)$ & $-0.006(0.007)$ & $-0.003(0.006)$ & $-0.002(0.011)$ & $-0.0008(0.011)$ \\
\hline Manufacturing & $-0.431(1.488)$ & $-0.646(1.426)$ & $0.833(0.843)$ & $0.716^{+}(0.783)$ & $2.019(1.402)$ & $2.000(1.370)$ \\
\hline Retail & $-1.601(1.512)$ & $-2.197(1.455)$ & $-0.127(0.864)$ & $-0.329(0.804)$ & $0.058(1.417)$ & 0.058 (1.389) \\
\hline Other industries & $-2.339(2.035)$ & $-3.152(1.972)$ & $2.037 *(1.152)$ & $1.470(1.082)$ & $2.320(1.936)$ & 1.837 (1.909) \\
\hline F-Test & $4.90^{* * *}$ & $5.29^{* * *}$ & $5.85^{* * *}$ & $7.15^{* * *}$ & $4.14^{* * *}$ & $4.09 * * *$ \\
\hline $\mathrm{R}^{2}$ & 0.24 & 0.33 & 0.28 & 0.40 & 0.21 & 0.27 \\
\hline Adjusted $\mathrm{R}^{2}$ & 0.19 & 0.27 & 0.23 & 0.34 & 0.16 & 0.20 \\
\hline $\mathrm{N}$ firms & 131 & 131 & 130 & 130 & 136 & 136 \\
\hline
\end{tabular}

$* * * \mathrm{p}<0.01$

$* * \mathrm{p}<0.05$.

$* \mathrm{p}<0.1$ (two-sided tests).

(Feliu \& Botero, 2016, p. 121), qualifying as philanthropic activity (Schuyt, 2010). Nevertheless, philanthropy is unlikely to be the only motivation for transferring firm equity to a charitable foundation, as there are many other ways (potentially less complicated) that business owners can help society. For example, he or she might simply sell the firm and donate the proceeds to a good cause. As discussed above, setting up a foundation-owned firm can also help solve family succession issues, reduce the impact of inheritance taxes, and secure the longrun existence of the firm. Thus, the motives are manifold and comprise many business- and family-related motives as well as philanthropic motives, which is in line with prior research about the philanthropy and social responsibility of family firms (Binz et al., 2013; Cruz et al., 2014; Dou et al., 2014; Feliu \& Botero, 2016).

From the firm perspective, our results point towards an important trade-off. While a charitable foundation as a firm owner may be good for society, it seems not to be beneficial for firm performance. Foundation-owned firms with charitable foundations as owners show weaker accounting performance than other foundation-owned firms. Having a stock market listing does not seem to compensate for this negative performance effect, as one might have expected.

\subsection{Implications for corporate governance research}

Our study also has implications for the field of corporate governance. First and foremost, it is surprising that our results do not show any performance effect of being listed on the stock market. One possible reason could be that since foundations are large and powerful blockholders, the stock market-induced effects are outweighed by blockholder effects (Gigler et al., 2014).

As already noted in the introduction, the corporate governance literature widely discusses ownership effects. The influential role of shareholders can be explained by the shareholder primacy view, which prioritizes shareholders over all company stakeholders and thus considers them the most important group in terms of profit maximization (Berle \& Means, 1991). Accordingly, agency theory states that shareholder protection is the most prevalent aspect of the corporate governance relationship (Jensen \& Meckling, 1976). Blockholders are seen from two angles in this regard. Blockholders can lead to a convergence of interest (De Miguel et al., 2004), which implies that they have a positive effect on performance, as they decrease agency conflicts by effectively monitoring management (Jensen \& Meckling, 1976). However, blockholders could also expropriate other (minority) shareholders by using their power to optimize their own interest (Shleifer \& Vishny,
1997). Furthermore, high ownership concentration is associated with ineffectiveness in regard to decision making and value maximization (for a good overview of a discussion on this topic, see Sánchez-Ballesta \& García-Meca, 2007). Both views need to take into account the heterogeneity of ownership and blockholder ownership. According to McNulty and Nordberg (2016), ownership can be seen from different angles, including the views of "law, psychology, sociology, and organizational studies" (p. 347). Our study sheds light on the influence of foundations as blockholders in different contexts as well as with differing characteristics. Thus, we support the view that a more differentiated analysis of shareholders is needed to disentangle the factors that affect performance. As we see a negative influence of charitable foundation ownership on all performance measures, we support the view that a less knowledgeable and probably less monitoring blockholder has a negative impact on performance. For family foundationowned firms, we can disentangle the effect of the families also involved in firm management, which has a positive impact on performance; the results for this case are in line with an incentivized monitoring and reduced agency-conflict hypothesis, confirming the convergence-of-interest theory. We encourage further research on the interrelation between the foundation and management, which should help us understand the psychological and organizational aspects of corporate governance issues.

A second interesting stream of the corporate governance literature highlights the difference between public and private companies. One advantage of being publicly listed is the easy transfer of ownership. Thus, changes in shareholders are rather normal for listed companies. The types of shareholders that trade frequently will not have a strong interest in the long-term development of the firm, while those shareholders interested in a long-term relationship will be more patient and supportive of long-term oriented actions. Meanwhile, private firms regularly show strong ownership concentration due to the inefficiencies of tradable shares. Prior research shows that management is more strongly monitored in private firms with a large number of shareholders (Cornelli et al., 2013) than in public firms with dispersed ownership. However, for listed foundation-owned firms, the foundation is a strong blockholder. Furthermore, foundations should have a strong incentive for monitoring the actions of management, or at least clear direction provided by the foundation charter. This incentive is discussed in research on family and private equity firm ownership (Maury \& Pajuste, 2005) and is expected to result in better performance. As we cannot find performance differences in our sample, we shed light on the role of influencing blockholders in public versus private firms, showing that 
the market monitoring of a private firm with a foundation as a strong blockholder does not work less efficiently than in public firms with the same blockholder type.

\subsection{Implications for practice}

The results of our study are not only relevant for academic research but also have practical implications, particularly for founders or founding families that consider transferring their equity to a foundation. Our results indicate that the family still plays an important role in foundation-owned firms. Keeping the family involved in the firm through a position in the firm's management or supervisory board or as the ultimate beneficiaries of the foundation seems to be beneficial for the firm and seems to have positive effects on firm performance. In contrast, the listing of foundation-owned firms on the stock market apparently does not have a performance-enhancing effect. When establishing a foundation as a solution to family business succession, founders or founding families need to think carefully about who takes on the role of active owners or entrepreneurs constantly monitoring and challenging the management of the firm. Our results indicate that the family can do this job relatively well, while being listed on the stock market seems not to make a difference. Establishing a foundation can create a difficult or even paradoxical situation. On the one hand, the motivation of the founders or founding families to transfer their equity to a foundation could be to reduce family influence on the firm; on the other hand, it appears to be just this link or influence that is beneficial for the foundation-owned firm. However, one needs to note that our results have to be interpreted with great caution as we did not account for selection effects (see also a discussion of the limitations below). Clearly, more research is needed about the precise circumstances and boundary conditions under which family involvement in foundationowned firms creates economic value.

\section{Limitations and future research}

Our study suffers from three main limitations. First, our analyses rely on a relatively small sample size because the number of foundation-owned firms in Germany is still limited and because many foundation-owned firms do not publish their accounting data. The research on foundation-owned firms is still relatively scarce, although this will likely change in the future since the practical interest in foundations as firm owners is growing steadily. Second, we cannot distinguish between the selection and treatment effects in our study. This means, for example, that we cannot distinguish whether the owners of poorer performing firms are particularly likely to choose a charitable foundation as a succession vehicle or whether the charitable foundation is the institution that causes poorer firm performance. Similarly, it might be only the highly competent and highly motivated family members who choose to work in a foundation-owned firm. Again, we cannot distinguish whether this selection or the positive influence of the foundation creates the performance-enhancing effect attributed to family involvement. Finally, given the stability of foundation status over time, we were not able to run panel analyses. Fellow scholars might build on research designs such as event studies to scrutinize firm performance before and after a foundation has been established.

Our study opens up several avenues for further research. First, one could try to gain a deeper understanding of the family involvement effects. In our analysis, we could not distinguish between family involvement in the management board or supervisory board. It would be interesting to learn whether the positive effects of family involvement are due to effective management control or due to effective (operational) management or both. Second, it would be interesting to replicate our study with firms from different countries and regions. In particular, Scandinavia would be a good choice, as it has a similar structure in terms of foundation-owned firms (Thomsen, 1996, 1999; Thomsen \& Rose, 2004). Third, it would be interesting to relate the precise reasons the owner decided to transfer his or her equity to the foundation with the later performance of the foundation-owned firm. One could expect a legacy or imprinting effect (Burton \& Beckman, 2007; Jaskiewicz et al., 2015; Kammerlander et al., 2015) in that the will or rationale of the founder to set up the foundation is imprinted on the firm and influences subsequent firm performance. Finally, differences within the group of foundation-owned firms may exist not only regarding performance but also regarding other firm outcomes. For example, one could expect charitable foundations as firm owners to influence the firm in such a way that the firm behaves in a more socially responsible and employee-friendly manner (Draheim \& Franke, 2018) than other types of foundation-owned firms. It would also be interesting to move beyond the firm perspective and to further scrutinize the philanthropic activities of charitable foundations that own firms. One could, for example, investigate how philanthropic activities of these charitable foundations would compare to those of other charitable foundations that do not own firms.

To summarize, research about foundation-owned firms and their interrelationships with business families is only beginning to draw scholarly attention. Clearly, more research is needed to gain a more comprehensive picture of the heterogeneity of foundation-owned firms and how this heterogeneity affects firm outcomes. Future research should also try to integrate and make more (explicit) use of theory in the study of foundation-owned firms. To date, most studies on foundation-owned firms (including ours) are phenomenon-driven and rather exploratory and descriptive in nature. As the study of foundationowned firms is at the intersection of several academic disciplines and research streams, multiple theories from different angles could be used. We hope that our study inspires family firm researchers to conduct research on this highly relevant and at the same time fascinating phenomenon.

\section{CRediT authorship contribution statement}

Jörn Block: Conceptualization, Methodology, Writing - original draft, Writing - review \& editing, Investigation, Supervision. Svenja Jarchow: Conceptualization, Methodology, Writing - original draft, Writing - review \& editing. Nadine Kammerlander: Conceptualization, Writing - original draft, Writing - review \& editing. Florian Hosseini: Conceptualization, Writing - original draft, Formal analysis, Investigation. Ann-Kristin Achleitner: Conceptualization, Writing original draft.

\section{Acknowledgements}

This research was supported by a research grant from the Jackstaedt-Foundation, Wuppertal, Germany. The foundation, however, was not involved in the actual research, nor was it involved in the writing or presentation of the results. A previous version of this paper was presented at the 22nd Annual Interdisciplinary Conference on Entrepreneurship and Innovation (G-Forum).

\section{References}

Abarbanell, J., \& Bernard, V. (2000). Is the US stock market myopic? Journal of Accounting Research, 38(2), 221-242.

Achleitner, A. K., \& Block, J. H. (2018). Stiftungsunternehmen als hybride Organisationen an der Schnittstelle zwischen Gewinn- und Gemeinwohlorientierung. In A. K. Achleitner, J. H. Block, \& R. Strachwitz (Eds.). Stiftungsunternehmen: Theorie und Praxis. Wiesbaden: Springer.

Achleitner, A. K., Bazhutov, D., Betzer, A., Block, J. H., \& Hosseini, F. (2018). Foundationowned firms and shareholder value. Review of Managerial Science. https://doi.org/10. 1007/s11846-018-0296-x.

Achleitner, A. K., Andres, C., Betzer, A., \& Weir, C. (2011). Wealth effects of private equity investments on the German stock market. European Journal of Finance, 17(3), 217-239.

Agrawal, A., \& Mandelker, G. N. (1990). Large shareholders and the monitoring of managers: The case of antitakeover charter amendments. The Journal of Financial and Quantitative Analysis, 25(2), 143-161. 
Andres, C. (2008). Large shareholders and firm performance - An empirical examination of founding-family ownership. Journal of Corporate Finance, 14(4), 431-445.

Arteaga, R., \& Menéndez-Requejo, S. (2017). Family constitution and business performance: Moderating factors. Family Business Review, 30(4), 320-338.

Bandiera, O., Lemos, R., Prat, A., \& Sadun, R. (2017). Managing the family firm: Evidence from CEOs at work. The Review of Financial Studies, 31(5), 1605-1653.

Barclay, M. J., \& Holderness, C. G. (1990). Negotiated block trades and corporate control. The Journal of Finance, 46(3), 861-878.

Basco, R. (2013). The family's effect on family firm performance: A model testing the demographic and essence approaches. Journal of Family Business Strategy, 4(1), $42-66$.

Bennedsen, M., Nielsen, K. M., Perez-Gonzalez, F., \& Wolfenzon, D. (2007). Inside the family firm: The role of families in succession decisions and performance. The Quarterly Journal of Economics, 122(2), 647-691.

Berle, A. A., \& Means, G. C. (1991). The modern corporation and private property (2nd edition). Transaction Publishers.

Besecke, M. K. (2015). Essays on family- and foundation-owned firms. Dissertation. Technische Universität München.

Bessler, W., Drobetz, W., \& Holler, J. (2015). The returns to hedge fund activism in Germany. European Financial Management, 21(1), 106-147.

Bethel, J. F., Porter, J., \& Opler, T. (1998). Block share purchases and corporate performance. The Journal of Finance, 53(1), 605-634.

Binz, C., Hair, J. F., Jr., Pieper, T. M., \& Baldauf, A. (2013). Exploring the effect of distinct family firm reputation on consumers' preferences. Journal of Family Business Strategy, 4, 3-11.

Block, J. H., \& Hosseini, F. (2017). Stiftungsunternehmen als hybride Organisationen: Auswirkungen auf die Unternehmensperformance. In B. Weitemeyer, R. Hüttemann, \& P. Rawert (Eds.). Non-Profit Law Yearbook 2016/2017. Bucerius Law School Press Hamburg.

Block, J. H., Jaskiewicz, P., \& Miller, D. (2011). Ownership versus management effects on performance in family and founder companies: A Bayesian reconciliation. Journal of Family Business Strategy, 2(4), 232-245.

Boehmer, E. (2000). Business groups, bank control, and large shareholders: An analysis of German takeovers. Journal of Financial Intermediation, 9(2), 117-148.

Børsting, C., \& Thomsen, S. (2017). Foundation ownership, reputation, and labour. Oxford Review of Economic Policy, 33(2), 317-338.

Brandmüller, G., \& Lindner, R. (2004). Gewerbliche Stiftungen (3rd revised edition). Hamburg/Duisburg.

Brauer, M. F. (2013). The effects of short-term and long-term oriented managerial behavior on medium-term financial performance: Longitudinal evidence from Europe. Journal of Business Economics and Management, 14(2), 386-402.

Brav, A., Jiang, W., Partnoy, F., \& Thomas, R. (2008). Hedge fund activism, corporate governance, and firm performance. The Journal of Finance, 63(4), 1729-1775.

Burkart, M., Panunzi, F., \& Shleifer, A. (2003). Family firms. The Journal of Finance, 58(5), $2167-2201$

Burton, M. D., \& Beckman, C. M. (2007). Leaving a legacy: Position imprints and successor turnover in young firms. American Sociological Review, 72(2), 239-266.

Bushee, B. J. (1998). The influence of institutional investors on myopic R\&D investment behavior. The Accounting Review, 73(3), 305-333.

Campopiano, G., De Massis, A., \& Chrico, F. (2014). Firm philanthropy in small- and medium-sized family firms: The effects of family involvement in ownership and management. Family Business Review, 27(3), 244-258.

Chen, Y. F., Lin, F. L., \& Yang, S. Y. (2015). Does institutional short-termism matter with managerial myopia? Journal of Business Research, 68(4), 845-850.

Chrisman, J. J., Chua, J. H., Pearson, A. W., \& Barnett, T. (2012). Family involvement, family influence, and family-centered non-economic goals in small firms. Entrepreneurship Theory and Practice, 36(2), 267-293.

Cornelli, F., Kominek, Z., \& Ljungqvist, A. (2013). Monitoring managers: Does it matter? The Journal of Finance, 68(2), 431-481.

Cruz, C., Larraza-Kintana, M., Garcés-Galdeano, L., \& Berrone, P. (2014). Are family firms really more socially responsible? Entrepreneurship Theory and Practice, 38, 1295-1316.

Davis, J. H., Allen, M. R., \& Hayes, H. D. (2010). Is blood thicker than water? A study of stewardship perceptions in family business. Entrepreneurship Theory and Practice, 43(6), 1093-1116.

De Massis, A., Chua, J. H., \& Chrisman, J. J. (2008). Factors preventing intra-family succession. Family Business Review, 21(2), 183-199.

De Miguel, A., Pindado, J., \& de la Torre, C. (2004). Ownership structure and firm value: New evidence from Spain. Strategic Management Journal, 25(12), 1199-1207.

Dou, J., Zhang, Z., \& Su, E. (2014). Does family involvement make firms donate more? Empirical evidence from Chinese private firms. Family Business Review, 27, 259-274.

Draheim, M. (2016). Three essays on foundation owned firms in Germany. Dissertation. Universität Konstanz.

Draheim, M., \& Franke, G. (2018). Employee orientation and financial performance of foundation owned firms. Schmalenbach Business Review, 1-36.

Dzansi, J. (2012). Foundation control and investment performance: Do intrinsic aspects of ownership and control matter? Global Economy and Finance Journal, 5(2), 58-78.

Feliu, N., \& Botero, I. C. (2016). Philanthropy in family enterprises: A review of literature. Family Business Review, 29(1), 121-141.

Fleisch, H., Eulerich, M., Krimmer, H., Schlüter, A., \& Stolte, S. (2018). Modell unternehmensverbundene Stiftung. In C. Mecking, \& E. Steinsdörfer (Eds.). Edition Stiftung \& Sponsoring Band 2. Erich Schmidt, Berlin.

Fleishman, J. L. (2003). Stiftungsführung und Unternehmenskontrolle in Deutschland und den Vereinigten Staaten: Die Bedeutung von Unabhängigkeit und Freiheit der Stiftungen für das Gemeinwohl. In Bertelsmann Stiftung (Ed.). Handbuch Stiftungen (pp. 352-391). (2nd edn.). Gabler: Wiesbaden.
Fleschutz, K. (2009). Die Stiftung als Nachfolgeinstrument für Familienunternehmen. Gabler, Wiesbaden.

Frank, H., Kessler, A., Nosé, L., \& Suchy, D. (2011). Conflicts in family firms: State of the art and perspectives for future research. Journal of Family Business Management, 1(2), 130-153.

Fricke, D. (2010). Unternehmensnachfolge mittels Stiftungen: Zivilrechtliche und steueroptimale Gestaltung. Marburg: Tectum Verlag.

Friedman, S. D. (1991). Sibling relationships and intergenerational succession in family firms. Family Business Review, 4(1), 3-20.

Fritsche, S., \& Kilian, U. (2008). Nachfolge in Familienunternehmen durch Unternehmensträgerstiftungen. Stiftung und Sponsoring, 3.

Gigler, F., Kanodia, C., Sapra, H., \& Venugopalan, R. (2014). How frequent financial reporting can cause managerial short-termism: An analysis of the costs and benefits of increasing reporting frequency. Journal of Accounting Research, 52(2), 357-387.

Götz, H., \& Berndt, H. (2009). Stiftung und Unternehmen - Zivilrecht, Steuerrecht, Gemeinnützigkeit (8th edition). Kerne.

Graves, S. B., \& Waddock, S. A. (1990). Institutional ownership and control: Implications for long-term corporate strategy. The Academy of Management Perspectives, 4(1), 75-83.

Hansen, C., \& Block, J. (2020). Exploring the relation between family involvement and firms' financial performance: A replication and extension meta-analysis (in press) Journal of Business Venturing Insights. https://doi.org/10.1016/j.jbvi.2020.e00158.

Hansen, C., Block, J., \& Neuenkirch, M. (2020). Family firm performance over the business cycle: A meta-analysis (in press) Journal of Economic Surveys. https://doi.org/10. 1111 /joes.12364.

Harford, J., Kecskes, A., \& Mansi, S. (2018). Do long-term investors improve corporate decision making? Journal of Corporate Finance, 50, 424-452.

Heinzelmann, J. (2002). Die Stiftung im Konzern. In Deutsches Stiftungszentrum (Ed.). Schriftenreihe zum Stiftungswesen, Band 27, Essen.

Henrekson, M., Johansson, D., \& Stenkula, M. (2019). The rise and decline of private foundations as controlling owners of Swedish listed firms: The role of tax incentives. Mimeo. https://www.ifn.se/wfiles/wp/wp1279.pdf.

Herrmann, M., \& Franke, G. (2002). Performance and policy of foundation-owned firms in Germany. European Financial Management, 8(3), 261-279.

Hillman, A. J., \& Dalziel, T. (2003). Boards of directors and firm performance: Integrating agency costs and resource dependence perspectives. The Academy of Management Review, 28(3), 383-396.

Holderness, C. (2003). A survey of blockholders and corporate control. Economic Policy Review, 9(1), 51-63.

Holderness, C., \& Sheehan, D. (1988). The role of majority shareholders in public held corporations. Journal of Financial Economics, 20(1), 317-346.

Holmström, B., \& Tirole, J. (1993). Market liqudity and performance monitoring. The Journal of Political Economy, 101(4), 678-709.

Jaskiewicz, P., Uhlenbruck, K., Balkin, D. B., \& Reay, T. (2013). Is nepotism good or bad? Types of nepotism and implications for knowledge management. Family Business Review, 26(2), 121-139.

Jaskiewicz, P., Combs, J., \& Rau, S. (2015). Entrepreneurial legacy: Toward a theory of how some family firms nurture transgenerational entrepreneurship. Journal of Business Venturing, 30(1), 29-49.

Jensen, M. C., \& Meckling, W. (1976). Theory of the firm: Managerial behavior, agency costs and ownership structure. Journal of Financial Economics, 3(4), 305-360.

Kammerlander, N., Dessi, C., Bird, M., Floris, M., \& Murru, A. (2015). The impact of shared stories on family firm innovation: A multicase study. Family Business Review, 28(4), 332-354.

Kennedy, C., Rumberg, D., \& Then, V. (1998). Die Organisation von Stiftungen: Personalentwicklung und Ressourcenmanagement. In Bertelsmann Stiftung (Ed.). Handbuch Stiftungen (pp. 423-472). Wiesbaden.

Kronke, H. (1988). Stiftungstypus und Unternehmensträgerstiftung: Eine rechtsvergleichende Untersuchung. Tübingen: Mohr Siebeck.

Laverty, K. J. (1996). Economic "short-termism": The debate, the unresolved issues, and the implications for management practice and research. The Academy of Management Review, 21(3), 825-860.

Lewellen, W., Loderer, C., \& Rosenfeld, A. (1985). Merger decisions and executive stock ownership in acquiring firms. Journal of Accounting and Economics, 7(1-3), 209-231.

Maier, F., Meyer, M., \& Steinbereithner, M. (2016). Nonprofit organizations becoming business-like: A systematic review. Nonprofit and Voluntary Sector Quarterly, 45(1), 64-86.

Marginson, D., \& McAulay, L. (2008). Exploring the debate on short-termism: A theoretical and empirical analysis. Strategic Management Journal, 29(3), 273-292.

Maury, C. B., \& Pajuste, A. (2005). Multiple large shareholders and firm value. Journal of Banking \& Finance, 29(7), 1813-1834.

McNulty, T., \& Nordberg, D. (2016). Ownership, activism and engagement: Institutional investors as active owners. Corporate Governance an International Review, 24(3), 346-358.

Miller, D., \& Le Breton-Miller, I. (2006). Family Governance and firm performance: Agency, stewardship and capabilities. Family Business Review, 19(1), 73-87.

Miller, D., Minichilli, A., \& Corbetta, G. (2013). Is family leadership always beneficial? Strategic Management Journal, 34(5), 553-571.

Moog, P., \& Schell, S. (2015). Stiftungsmanagement als Nachfolgelösung. In W. Becker, \& P. Ulrich (Eds.). Mittelstandsorientierte Betriebswirtschaftslehre. Ein Handbuch (pp. 815829). Kohlhammer, Stuttgart.

Morck, R., Shleifer, A., \& Vishny, R. W. (1988). Management, ownership and market valuation: An empirical analysis. Journal of Financial Economics, 20, 293-315.

Morck, R., Wolfenzon, D., \& Yeung, B. (2005). Corporate governance, economic entrenchment, and growth. Journal of Economic Literature, 43(3), 655-720.

O'Boyle, E. H., Jr., Pollack, J. M. \& Rutherford, M. W. (2012). Exploring the relation 
between family involvement and firms' financial performance: A meta-analysis of main and moderator effects. Journal of Business Venturing, 27(1), 1-18.

Pagano, M., \& Röell, A. (1998). The choice of stock ownership structure: Agency costs, monitoring, and the decision to go public. The Quarterly Journal of Economics, 113(1), $187-225$.

Pagano, M., Panetta, F., \& Zingales, L. (1998). Why do companies go public? An empirical analysis. The Journal of Finance, 53(1), 27-64.

Palley, T. I. (1997). Managerial turnover and the theory of short-termism. Journal of Economic Behavior \& Organization, 32(4), 547-557.

Renneboog, L., Simons, T., \& Wright, M. (2007). Why do public firms go private in the UK? The impact of private equity investors, incentive realignment and undervaluation. Journal of Corporate Finance, 13(4), 591-628.

Sánchez-Ballesta, J. P., \& García-Meca, E. (2007). A meta-analytic vision of the effect of ownership structure on firm performance. Corporate Governance an International Review, 15(5), 879-892.

Scholes, L., Wright, M., Westhead, P., \& Bruining, H. (2010). Strategic changes in family firms post management buyout: Ownership and governance issues. International Small Business Journal, 28(5), 505-521.

Schuyt, T. N. M. (2010). Philanthropy in European welfare states: A challenging promise? International Review of Administrative Sciences, 76, 774-789.

Sciascia, S., Mazzola, P., \& Kellermanns, F. W. (2014). Family management and profitability in private family-owned firms: Introducing generational stage and the socioemotional wealth perspective. Journal of Family Business Strategy, 5(2), 131-137.

Sharma, P., Chrisman, J., Pablo, A. L., \& Chua, J. (2001). Determinants of initial satisfaction with the succession process in family firms: A conceptual model. Entrepreneurship Theory and Practice, 25(3), 17-35.

Shleifer, A., \& Vishny, R. W. (1997). A survey of corporate governance. The Journal of Finance, 52(2), 737-783.

Stein, J. C. (1988). Takeover threats and managerial myopia. The Journal of Political Economy, 96(1), 61-80.

Stein, J. C. (1989). Efficient capital markets, inefficient firms: A model of myopic corporate behavior. The Quarterly Journal of Economics, 104(4), 655-669.

Stickrodt, G. (1960). Probleme zur rechtlichen Struktur von Stiftungsunternehmen, Baden Baden.
Suarez, D. F. (2010). Street credentials and management backgrounds: Careers of nonprofit executives in an evolving sector. Nonprofit and Voluntary Sector Quarterly, 39(4), 696-716.

Suess, J. (2014). Family governance - Literature review and the development of a conceptual model. Journal of Family Business Strategy, 5(2), 138-155.

Thomsen, S. (1996). Foundation ownership and economic performance. Corporate Governance an International Review, 4(4), 212-221.

Thomsen, S. (1999). Corporate ownership by industrial foundations. European Journal of Law and Economics, 7(2), 1095-1117.

Thomsen, S. (2012). What do we know (and not know) about industrial foundations. Working paper.

Thomsen, S. (2017). The Danish industrial foundations. Jurist Forlag.

Thomsen, S., \& Hansmann, H. (2014). The performance of foundation-owned companies. SSRN working paper.

Thomsen, S., \& Rose, C. (2004). Foundation ownership and financial performance: Do companies need owners? European Journal of Law and Economics, 18(3), 343-364.

Vinton, K. L. (1998). Nepotism: An interdisciplinary model. Family Business Review, 11(4), 297-303.

Volpin, P. F. (2002). Governance with poor investor protection: Evidence from top executive turnover in Italy. Journal of Financial Economics, 64(1), 61-90.

von Camphausen, A., \& Richter, A. (2014). Stiftungsrechts-Handbuch (4th edition). München.

Wagner, D., Block, J. H., Miller, D., Schwens, C., \& Xi, G. (2015). A meta-analysis of the financial performance of family firms: Another attempt. Journal of Family Business Strategy, 6(1), 3-13.

Zeckhauser, R., \& Pund, J. (1990). Are large shareholders effective monitors? An investigation of share ownership and corporate performance. In R. G. Hubbard (Ed.). Asymmetric information, corporate finance and investment (pp. 149-180). Chicago: University of Chicago Press.

Zeiter, A. (2004). Errichtung einer Unternehmensstiftung: Attraktive Option in der Nachlassregelung. Der Schweizer Treuhänder, 10(4), 841-848.

Zellweger, T., \& Kammerlander, N. (2015). Family wealth governance: An agency perspective. Entrepreneurship Theory and Practice, 39(6), 1281-1303. 